\title{
Capillary haemangioma of fallopian tube: a rare but dangerous incidental finding
}

\author{
Shakti Kumar Yadav', Mishika Bhoj ${ }^{2}$, Sudha Salhan ${ }^{2}$, Namrata Sarin ${ }^{1}$, Sompal Singh $^{1 *}$
}

\begin{abstract}
${ }^{1}$ Department of Pathology, ${ }^{2}$ Department of Obstetrics and Gynecology, North Delhi Municipal Corporation Medical College and Hindu Rao Hospital, New Delhi, India
\end{abstract}

Received: 05 December 2018

Accepted: 29 December 2018

\author{
*Correspondence: \\ Dr. Sompal Singh, \\ E-mail: sompal151074@gmail.com
}

Copyright: (c) the author(s), publisher and licensee Medip Academy. This is an open-access article distributed under the terms of the Creative Commons Attribution Non-Commercial License, which permits unrestricted non-commercial use, distribution, and reproduction in any medium, provided the original work is properly cited.

\begin{abstract}
Haemangiomas are tumors of vascular origin. They are frequently observed in soft tissue and skin. Vascular tumors of female pelvic organs are extremely rare. Although, majority of these lesions are detected incidentally, they can mimic various benign and malignant lesions clinically and radiologically. Fallopian tube capillary haemangioma is very rare benign neoplasm. Only one case of capillary haemangioma of fallopian tube has been reported. A 44-year-old female with menorrhagia, underwent hysterectomy with bilateral salpingoopherectomy. Both the fallopian tubes were grossly unremarkable. Microscopic examination revealed a well circumscribed vascular neoplasm, consistent with capillary haemangioma, CD34 immunostaining highlighted the vascular endothelium. Although benign in nature, haemangioma of the fallopian tube can present with complications. Rupture of the haemangioma can be lethal when present with hemoperitoneum.
\end{abstract}

Keywords: Capillary, Cavernous, Fallopian tube, Hemangioma

\section{INTRODUCTION}

Female pelvic organs are extremely rare site for the haemangiomas. ${ }^{1}$ Many authors have attributed this to the rich vascular supply and reproductive cyclical changes. Fallopian tube neoplasms are uncommon tumours of female genital organs, most common benign tumor being endometrioid polyp occurring at the interstitial portion. ${ }^{2}$ Fallopian tube haemangioma was first reported by Ragins et al, in 1947, since then only twelve cases have been reported in the literature, eleven of which were cavernous haemangioma and only one case of capillary haemangioma is reported..$^{2-4}$

Majority of haemangioma of female pelvic organs are detected incidentally, but they can mimic various benign and malignant lesions clinically and radiologically. Clinically, haemangiomas can present as bluish discoloration. Pain after exercise may occur due to shunting of blood flow away from the surrounding tissue into the haemangioma. Radiologically, haemangiomas can be found to have serpentine vessels and soft tissue. ${ }^{4}$

Histologically, haemangiomas are categorized on the basis of predominant vascular channel type i.e. capillary or cavernous. Cavernous haemangiomas are common in skin as well as in liver, breast and skeletal muscle. It is characterized by wider cavern type vascular channels lined by bland looking endothelial cells. ${ }^{4}$ While, capillary haemangiomas consist of proliferating and sprouting capillaries, which gradually form canaliculi lined by single layer of endothelium. ${ }^{5}$ Authors present a case of capillary haemangioma of fallopian tube which was detected incidentally in a post-menopausal female who underwent hysterectomy with salpingoopherectomy for abnormal uterine bleeding. 


\section{CASE REPORT}

A 44-year-old female patient presented with history of menorrhagia for eight months. She was diabetic and hypertensive. Her last child birth was 18 years back (normal vaginal delivery). The per-speculum examination of the patient revealed hypertrophied cervix with cervical erosion. Per-vaginal examination revealed anteverted bulky uterus, bilateral fornices were free and non-tender. Ultrasonography examination showed an intramural leiomyoma of $1.5 \times 1.2 \mathrm{~cm}$. Both ovaries and fallopian tubes were unremarkable. Total abdominal hysterectomy with bilateral salpingoopherectomy was done. On gross examination, uterus and cervix were unremarkable and altogether measured $12 \times 9 \times 5 \mathrm{~cm}$, bilateral fallopian tubes and ovaries were also grossly unremarkable. Histological sections examined revealed cervix showing feature of mild chronic cervicitis, endometrium was in secretory phase, myometrium showed presence of leiomyoma.

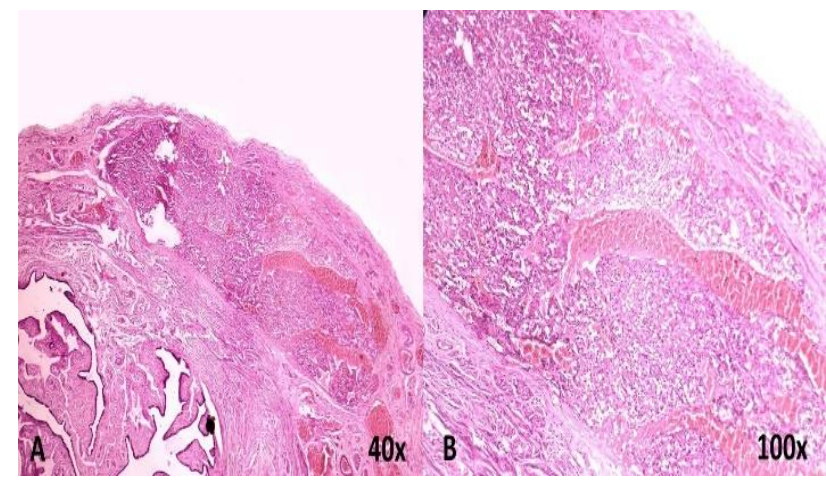

Figure 1: Photomicrograph showing a well circumscribed nodule in the wall of fallopian tube ( $\mathrm{A}$ -

$\mathrm{H}$ and $\mathrm{E}, 40 \mathrm{x})$; nodule is composed of thin walled capillary sized vessels filled with blood (B-H and E, 100x).

Sections from both ovaries and right fallopian tube were also unremarkable. Section from left fallopian tube showed unremarkable lumen and mucosal lining, the sub serosal region showed a well circumscribed vascular lesion of approximately $2 \mathrm{~mm}$ in maximum diameter.

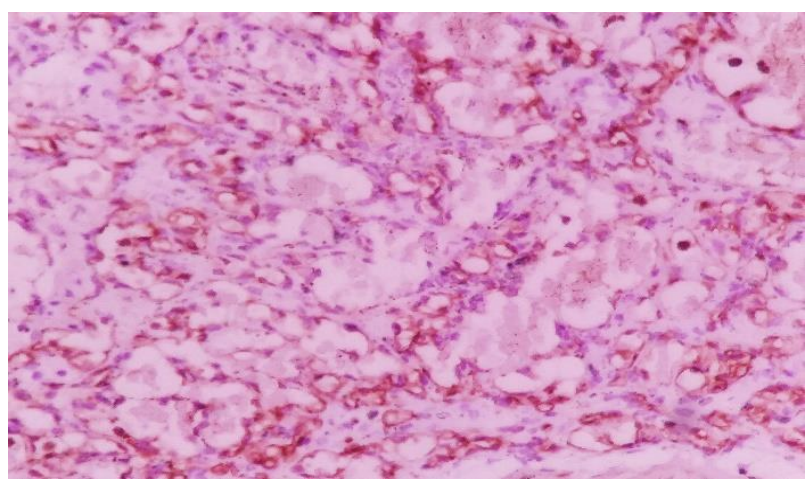

Figure 2: Photomicrograph showing CD34 immunostaining in capillary endothelial lining (DAB, 400x).
The lesion composed of thin walled proliferating capillary sized vessels filled with blood and were lined by endothelial cells (Figure 1).

Immunostaining for CD34 was done which highlighted the endothelial lining of the vascular channels (Figure 2). The lesion was diagnosed as subserosal capillary haemangioma of left fallopian tube.

\section{DISCUSSION}

Oviductal hemangioma have been reported in patients of 13-77 years of age (Table1). In majority of reported cases fallopian tube hemangioma was found in left tube. Size of lesion ranged from 0.2 to $3.5 \mathrm{~cm}$. Mostly, presenting as a small nodule or bulge in tubal wall. ${ }^{2,3,6-8}$ However, in few cases the lesion was found inside the tubal lumen filling it as hemorrhagic mass. ${ }^{9-11}$ In the present case, the lesion was present in left fallopian tube and the tube was grossly normal.

In the present case the patient was operated for menorrhagia. In previous case reports, the reason for surgery varied from abnormal uterine bleeding and vaginal discharge. In case reported by Patel DR et al, the patient presented with pain in right lower quadrant of abdomen and was clinically diagnosed as acute appendicitis. ${ }^{11}$ The patient had hemoperitoneum and fimbrial mass in the right fallopian tube. This was followed by right salpingectomy and appendectomy. On histology, it was diagnosed as cavernous hemangioma. Similar to this, in case reports by Gowri et al and AtereRoberts et al the patient had right lower quadrant pain and was operated for appendicitis, which was later found to have hemoperitoneum and right tubal mass., ${ }^{9,13}$ Joglekar VM et al reported a case of 24 year female with pain in left abdomen, she was clinically diagnosed as torsion of ovarian cyst. ${ }^{10}$ While in case reports by Ebrahimi $\mathrm{T}$ et al and Woznar $\mathrm{A}$ et al the patient was operated for endometrial adenocarcinoma (Table 1)..$^{5,7}$ Two out of twelve cases mentioned have endometrial carcinoma. Ebrahimi $\mathrm{T}$ et al proposed that hormonal therapy and radiation exposure might explain the occurrence of hemangioma in their patient. ${ }^{7}$ They suggested that, hemangioma might develop during the onset of menstruation or pregnancy, as the number and size of blood vessels increases under the effect of sex hormones. Atere-Roberts et al and Gowri et al also suggested that rise in sex hormone levels might be responsible for hemangioma as both their cases presented within few months after menarche., ${ }^{9,13}$

However, in eight of the remaining cases no such association was mentioned. Out of all the reported cases of fallopian tube hemangioma, only one case of capillary hemangioma has been reported. Authors are thus, presenting the second case of capillary hemangioma of the fallopian tube. The lesion in present case was found incidentally, without any obvious clinical or gross finding. 
Table 1: Clinicopathological features of fallopian tube haemangiomas.

\begin{tabular}{|c|c|c|c|c|c|c|c|c|c|c|c|}
\hline Author & $\begin{array}{l}\text { Age } \\
\text { (years) }\end{array}$ & $\begin{array}{l}\text { Presenting } \\
\text { symptom }\end{array}$ & $\begin{array}{l}\text { Clinical } \\
\text { diagnosis }\end{array}$ & $\begin{array}{l}\text { Associated } \\
\text { diagnosis }\end{array}$ & $\begin{array}{l}\text { Treat } \\
\text { ment }\end{array}$ & $\begin{array}{l}\text { Gross } \\
\text { findings }\end{array}$ & Side & Site & Size & $\begin{array}{l}\text { IHC } \\
\text { findings }\end{array}$ & $\begin{array}{l}\text { Histological } \\
\text { findings }\end{array}$ \\
\hline $\begin{array}{l}\text { Ragins } \\
\text { et } \text { al }^{3}\end{array}$ & 28 & $\begin{array}{l}\text { Dysmenorrhea } \\
\text { and abdominal } \\
\text { pain }\end{array}$ & $\begin{array}{l}\text { Tubo } \\
\text { ovarian } \\
\text { disease }\end{array}$ & None & LSO & $\begin{array}{l}\text { Dark purplish to } \\
\text { red, polypoidal } \\
\text { mass filling the } \\
\text { entire lumen }\end{array}$ & $\mathrm{L}$ & $\begin{array}{l}\text { Fimbria } \\
\text { end }\end{array}$ & $1.5 \mathrm{~cm}$ & None & $\begin{array}{l}\text { Cavernous } \\
\text { haemangioma }\end{array}$ \\
\hline $\begin{array}{l}\text { Gusman } \\
12\end{array}$ & 77 & $\begin{array}{l}\text { Found on } \\
\text { autopsy }\end{array}$ & None & Meningitis & None & Not mentioned & $\mathrm{L}$ & $\begin{array}{l}\text { Outer } \\
\text { one } \\
\text { third }\end{array}$ & $\begin{array}{l}\text { Not } \\
\text { men- } \\
\text { tioned }\end{array}$ & None & $\begin{array}{l}\text { Cavernous } \\
\text { haemangioma }\end{array}$ \\
\hline Talerma $^{8}$ & 23 & Dysmenorrhea & $\begin{array}{l}\text { Not } \\
\text { mentioned }\end{array}$ & $\begin{array}{l}\text { Mental } \\
\text { abnormality }\end{array}$ & $\begin{array}{l}\mathrm{H}+ \\
\mathrm{LSO}\end{array}$ & $\begin{array}{l}\text { Small round } \\
\text { reddish-brown } \\
\text { lesion bulging } \\
\text { into the lumen }\end{array}$ & $\mathrm{L}$ & $\begin{array}{l}\text { Middle } \\
\text { one } \\
\text { third }\end{array}$ & $0.5 \mathrm{~cm}$ & None & $\begin{array}{l}\text { Cavernous } \\
\text { haemangioma }\end{array}$ \\
\hline $\begin{array}{l}\text { Ebrahimi } \\
\text { et } \mathrm{al}^{7}\end{array}$ & 66 & $\begin{array}{l}\text { Discharge } \\
\text { per vaginum }\end{array}$ & $\begin{array}{l}\text { Not } \\
\text { mentioned }\end{array}$ & $\begin{array}{l}\text { Endo- } \\
\text { metrial } \\
\text { adeno- } \\
\text { carcinoma }\end{array}$ & $\begin{array}{l}\mathrm{H}+ \\
\mathrm{BSO}\end{array}$ & Slight bulge & $\mathrm{L}$ & $\begin{array}{l}\text { Mid } \\
\text { portion }\end{array}$ & $0.8 \mathrm{~cm}$ & None & $\begin{array}{l}\text { Cavernous } \\
\text { haemangioma }\end{array}$ \\
\hline $\begin{array}{l}\text { Patel et } \\
\text { al }^{11}\end{array}$ & 30 & $\begin{array}{l}\text { Pain in right } \\
\text { lower quadrant } \\
\text { of abdomen }\end{array}$ & $\begin{array}{l}\text { Acute } \\
\text { appendicitis }\end{array}$ & $\begin{array}{l}\text { Hemo- } \\
\text { peritoneum }\end{array}$ & $\begin{array}{l}\mathrm{RS}+ \\
\mathrm{A}\end{array}$ & $\begin{array}{l}\text { Encapsulated, } \\
\text { spongy, slightly } \\
\text { transparent mass } \\
\text { with blood filled } \\
\text { cystic spaces }\end{array}$ & $\mathrm{R}$ & Fimbria & $3.5 \mathrm{~cm}$ & None & $\begin{array}{l}\text { Cavernous } \\
\text { haemangioma }\end{array}$ \\
\hline $\begin{array}{l}\text { Joglekar } \\
\text { et al }{ }^{10}\end{array}$ & 24 & $\begin{array}{l}\text { Pain in lower } \\
\text { abdomen }\end{array}$ & $\begin{array}{l}\text { Torsion of } \\
\text { ovarian cyst }\end{array}$ & $\begin{array}{l}\text { Hemo- } \\
\text { peritoneum }\end{array}$ & LS & $\begin{array}{l}\text { Dilated lumen } \\
\text { filled with } \\
\text { blood clot }\end{array}$ & $\mathrm{L}$ & Fimbria & $2.0 \mathrm{~cm}$ & None & $\begin{array}{l}\text { Cavernous } \\
\text { haemangioma }\end{array}$ \\
\hline $\begin{array}{l}\text { Gowri } \\
\text { et } \mathrm{al}^{13}\end{array}$ & 13 & $\begin{array}{l}\text { Pain in right } \\
\text { lower quadrant } \\
\text { of abdomen }\end{array}$ & $\begin{array}{l}\text { Acute } \\
\text { appendicitis }\end{array}$ & $\begin{array}{l}\text { Hemo- } \\
\text { peritoneum }\end{array}$ & $\mathrm{RS}$ & Not mentioned & $\mathrm{R}$ & Ampula & $\begin{array}{l}6 \mathrm{~cm} \\
\text { on } \\
\text { USG }\end{array}$ & None & $\begin{array}{l}\text { Cavernous } \\
\text { haemangioma }\end{array}$ \\
\hline $\begin{array}{l}\text { Atere- } \\
\text { Roberts } \\
\text { et al }{ }^{9}\end{array}$ & 14 & $\begin{array}{l}\text { Pain in right } \\
\text { lower quadrant } \\
\text { of abdomen }\end{array}$ & $\begin{array}{l}\text { Acute } \\
\text { appendicitis }\end{array}$ & $\begin{array}{l}\text { Hemo- } \\
\text { peritoneum }\end{array}$ & $\begin{array}{l}\mathrm{RS}+ \\
\mathrm{A}\end{array}$ & $\begin{array}{l}\text { Dilated tubal } \\
\text { segment with } \\
\text { hemorrhagic } \\
\text { mass }\end{array}$ & $\mathrm{R}$ & $\begin{array}{l}\text { Not } \\
\text { men- } \\
\text { tioned }\end{array}$ & $3.5 \mathrm{~cm}$ & None & $\begin{array}{l}\text { Cavernous } \\
\text { haemangioma }\end{array}$ \\
\hline $\begin{array}{l}\text { Woznar } \\
\text { et } \mathrm{al}^{5}\end{array}$ & 69 & None & $\begin{array}{l}\text { Not } \\
\text { mentioned }\end{array}$ & $\begin{array}{l}\text { Endo- } \\
\text { metrial } \\
\text { Adeno- } \\
\text { carcinoma }\end{array}$ & $\begin{array}{l}\mathrm{H}+ \\
\mathrm{BSO}\end{array}$ & Not mentioned & $\mathrm{L}$ & $\begin{array}{l}\text { Not } \\
\text { men- } \\
\text { tioned }\end{array}$ & $0.3 \mathrm{~cm}$ & None & $\begin{array}{l}\text { Cavernous } \\
\text { haemangioma }\end{array}$ \\
\hline $\begin{array}{l}\text { Deb et } \\
\mathrm{al}^{6}\end{array}$ & 50 & Dysmenorrhea & $\begin{array}{l}\text { Not } \\
\text { mentioned }\end{array}$ & $\begin{array}{l}\text { Adeno- } \\
\text { myosis }\end{array}$ & $\begin{array}{l}\mathrm{H}+ \\
\mathrm{BSO}\end{array}$ & $\begin{array}{l}\text { Solid cystic } \\
\text { nodule with } \\
\text { congestion }\end{array}$ & $\mathrm{L}$ & Ampula & $3.0 \mathrm{~cm}$ & $\begin{array}{l}\text { CD34+, } \\
\text { CD31+, } \\
\text { EMA-, } \\
\text { LYVE- }\end{array}$ & $\begin{array}{l}\text { Cavernous } \\
\text { haemangioma }\end{array}$ \\
\hline $\begin{array}{l}\text { Katiyar } \\
\text { et } \mathrm{al}^{2}\end{array}$ & 30 & Dysmenorrhea & $\begin{array}{l}\text { Not } \\
\text { mentioned }\end{array}$ & $\begin{array}{l}\text { Not } \\
\text { mentioned }\end{array}$ & BSO & $\begin{array}{l}\text { Solid nodule } \\
\text { in tubal wall }\end{array}$ & $\mathrm{L}$ & $\begin{array}{l}\text { Not } \\
\text { men- } \\
\text { tioned }\end{array}$ & $0.2 \mathrm{~cm}$ & CD34+ & $\begin{array}{l}\text { Capillary } \\
\text { haemangioma }\end{array}$ \\
\hline $\begin{array}{l}\text { Kim et } \\
\mathrm{al}^{4}\end{array}$ & 49 & None & $\begin{array}{l}\text { Not } \\
\text { mentioned }\end{array}$ & $\begin{array}{l}\text { Tubo- } \\
\text { ovarian } \\
\text { endo- } \\
\text { metriosis } \\
\text { and HSIL in } \\
\text { cervix }\end{array}$ & $\begin{array}{l}\mathrm{H}+ \\
\mathrm{RSO}\end{array}$ & $\begin{array}{l}\text { Thickened } \\
\text { tubal segment } \\
\text { with blood } \\
\text { filled cystic } \\
\text { spaces }\end{array}$ & $\mathrm{R}$ & Ampula & $1.2 \mathrm{~cm}$ & $\begin{array}{l}\text { CD34+, } \\
\text { CD31+, } \\
\text { D2-40- }\end{array}$ & $\begin{array}{l}\text { Cavernous } \\
\text { haemangioma }\end{array}$ \\
\hline
\end{tabular}

$\mathrm{H}=$ Hysterectomy, TAH = Total abdominal hysterectomy, BSO = Bilateral salpingoopherectomy, RSO = Right salpingoopherectomy, LSO = Left salpingoopherectomy, RS = Right salpingectomy, LS = Left salpingectomy, A= Appendectomy, L = Left, $\mathrm{R}=\mathrm{Right}$

However, in case reported by Katiyar et al there was a tiny nodule in the wall of the fallopian tube. ${ }^{2}$ Although histological diagnosis of haemangioma is usually unequivocal, differential diagnosis include lesion like lymphangioma, vascular leiomyoma, adenomatoid tumor and mesothelioma. ${ }^{4}$ Immunohistochemical staining is helpful in differentiation. Hemangioma are positive for CD34 and CD31 along with smooth muscle actin and vimentin, however $\mathrm{Ki}-67$ expression is low (helps to differentiate from malignant vascular lesion) and negative to LYVE-1 (differentiation from lymphangioma).
Mesothelioma and adenomatoid tumor are positive for mesothelial markers like calretinin, WT-1 and D2-40. Vascular leiomyoma is positive for caldesmon, desmin and SMA. In the present case we found the positivity for CD34 in the endothelial cells cavernous channels. ${ }^{2,4}$

Treatment of hemangioma of fallopian tube is surgical excision of the lesion. In all the reported cases, no recurrences have been reported. However, follow up of patient may be done for similar lesions at other sites and other rare causes of congenital hemangioma. ${ }^{2}$ 


\section{CONCLUSION}

To conclude, this is the second reported case of capillary haemangioma of fallopian tube. Nevertheless, haemangioma of fallopian tube is extremely rare. Surgeon and pathologist must be observant while examining the fallopian tube. Rarely, rupture of benign haemangioma of fallopian tube may lead to fatal hemoperitoneum.

Funding: No funding sources

Conflict of interest: None declared

Ethical approval: Not required

\section{REFERENCES}

1. Gupta R, Singh S, Nigam S, Khurana N. Benign vascular tumors of female genital tract. Int J Gynecol Cancer. 2006;16:1195-200.

2. Katiyar R, Patne SC, Bharti S, Jain M. Capillary hemangioma of the fallopian tube. J Clin Diagn Res. 2016;10:QD01-2.

3. Ragins $\mathrm{AB}$, Crane RD. Cavernous hemangioma of the fallopian tube. Am J Obstet Gynecol. 1947;54:883-6.

4. Yoon G, Kim HS. Characterization of clinicopathological features of tubal cavernous hemangioma. Int $\mathbf{J}$ Clinic Experiment Pathol. 2016;9:7476-81.

5. Wojnar A, Drozdz K, Dziegiel P. Cavernous haemangioma of the oviduct. Pol $\mathrm{J}$ Pathol. 2010;61:103-4.
6. Deb P, Singh V, Dutta V, Kapoor K. An unusual case of cavernous haemangioma of the Fallopian tube. J Cancer Res Ther. 2014;10:363-4.

7. Ebrahimi T, Okagaki T. Hemangioma of the Fallopian tube. Am J Obstet Gynecol. 1973;115:8645.

8. Talerman A. Haemangioma of the fallopian tube. J Obstet Gynaecol Br Commonw. 1969;76:559-60.

9. Atere-Roberts N, Angelopoulos L, Ghataura S, Vijayanand R. Cavernous haemangioma of the fallopian tube presenting as appendicitis in an adolescent girl. J Obstet Gynaecol. 2010;30:70-1.

10. Joglekar VM. Haemangioma of the fallopian tube. Case report. Br J Obstet Gynaecol. 1979;86:823-5.

11. Patel DR, Kawalek R, Iger J. Cavernous hemangioma of the fallopian tube. Int Surg. 1973;58:420-1.

12. Gusmano G. Angioma of the Fallopian tubes; anatomopathological contribution. Minerva Ginecol. 1951;3:616-20.

13. Gowri R, Soundararaghavana S, Oumachigui A, Iyengar K. Fallopian tube haemangioma. J Obstet Gynecol Ind. 2004;54:85-6.

Cite this article as: Yadav SK, Bhoj M, Salhan S, Sarin N, Singh S. Capillary haemangioma of fallopian tube: a rare but dangerous incidental finding. Int J Reprod Contracept Obstet Gynecol 2019;8:747-50. 